\title{
S4 prescribing for podiatrists
}

Stephen Marty

From Australasian Podiatry Council Conference 2011

Melbourne, Australia. 26-29 April 2011

This session will cover the legislation affecting the prescribing of scheduled medicines by endorsed podiatrists, possession, administration and supply. It will include the differences between state and territory drugs and poisons requirements, issues in the preparation of prescriptions and what can go wrong. Risk management and the role of podiatrists in the quality use of medicines in Australia will also be discussed.

Published: 20 May 2011

Submit your next manuscript to BioMed Central and take full advantage of:

- Convenient online submission

- Thorough peer review

- No space constraints or color figure charges

- Immediate publication on acceptance

- Inclusion in PubMed, CAS, Scopus and Google Scholar

- Research which is freely available for redistribution 